\title{
The Cultivation and Exploration of Students' Innovative Ability in the Art Practice of Music Major in Normal Universities
}

\author{
Fan Qi \\ School of Music, Xianyang Normal University, Shaanxi, China, 712000
}

Keywords: Music major; art practice; innovation ability

Abstract: Practice can be said to be a very important part in any discipline, and art practice is more important for music majors. Music must not only have a good grasp of theoretical knowledge, but also a strong practical ability. Only in practice can you be flexible in applying what you have learned. This paper starts with the cultivation and exploration of students' innovative ability in the art practice of music major in higher normal colleges, puts forward the feasible opinions and suggestions on students' art practice, analyzes the ways of practicing art practice in higher normal colleges, and puts forward some points. The method of training students' innovative ability and the principles of implementation.

Music is an abstract and independent discipline. Abstraction is because the nature of music major requires students to have good thinking imagination. Music majors are more about feelings and feelings, and the ability to understand a certain work. We have strong imagination. Independence is different from other disciplines in music. Other disciplines are more knowledge in books, and music must not only have a good grasp of theoretical knowledge, but also a strong ability to use. Both of these factors are closely related to art practice. Only in practice can they be very good and flexible to apply what they have learned.

In addition to the flexible use of the theoretical and technical skills that he has learned, he also has a strong ability to innovate. Now the talents needed by society have shifted from possession to innovative talents. People can't use the same words. The porters of knowledge are more about re-innovation of knowledge and re-innovation of technology. Music majors are no exception. Because of the special nature of music, innovative talents are especially important. I think that music should show its personality. Everyone has to show their own style. Everyone has My own characteristics, there are no identical people in the world, and music does not have the same music. We must be good at innovation, show ourselves in innovation, and surpass ourselves. This requires each of our music learners to develop their own innovative abilities in the learning process so that they can be used better. 


\section{The effect of artistic practice of music majors in higher normal colleges on the cultivation of students' creative ability}

\subsection{Art practice can stimulate students' interest in innovation}

It is often said that interest is the best teacher in the child's learning process. In the process of people's learning, he can promote people to learn new things and explore new things. In the activities of art practice, students often show high enthusiasm. The practical activities and the knowledge in the books in the classroom are very different. In the classroom learning, the students are cautious, and the theory often has no practical effect. . In the process of practical activities, students can actively discover problems, think about them, curiosity about the problem, truly realize their hands-on ability, use their various ways of thinking to explore the problem according to their interest in music, and finally The problem is solved by various methods. Therefore, a strong interest in each artistic practice plays an important role in the students' operations in all aspects of the practical activities.

For example, when learning piano performance, we violated the composer's meaning when playing piano music. At this time, we will trace back to the meaning and creative background of the work itself, and bring us the motivation of thinking, and also mentioned us. Discover the interest of the problem. In order to change the previous problems, and then innovate on the basis of correct performance, the original intention of the work is sublimated, and the performance is more vivid.

\subsection{Art practice can guide students to have the correct way of creation}

At present, many college students have a certain degree of problems in their initiative to innovate their minds, such as the lack of self-learning, self-thinking ability, etc. Many students face similar problems when they face problems. They do not go from their own perspectives and other aspects. To solve the problem, the requirements that students should follow in practice are related to the type of artistic practice. Therefore, students should not think in the traditional way in the process of artistic practice, but should look at it from a unique perspective. Problem and solve the problem. The so-called correct way of creation means, for example, if you want to plant a flower that can open five color petals, then such innovation should start with how to solve the problem from the inside of the variety, do grafting, etc., so that its gene can be Open colorful flowers; instead of thinking about changing from the outside, the paint is painted, then this is the wrong way of creation.

Practice is done in real life, and some of the problems that arise are still problems that can be solved in reality, and are also based on reality. If there is no practice, all the ways of creation are unrealistic, and they can only be fantasy. All efforts are futile. Therefore, art practice can guide students to have the correct way of creation and move in the right direction.

In this way, we can not only see the connection between the essence of things and reality, but also on this basis, we can produce some unique creative achievements. Therefore, we say that innovative thinking is a kind of psychological activity that explores the unknown. This kind of activity can break the traditional model, but it can not break the real life, and on this basis, it can solve the problem. 
2. Second, the basic methods and teaching principles of art practice in the music major of normal universities

\subsection{The basic method of artistic practice in higher normal colleges and universities}

In the course of arranging courses, higher normal colleges should incorporate artistic practice. Students can only be qualified after completing artistic practice activities. The professional training objectives should be integrated into the art practice activities, and a detailed syllabus should be formulated. In this syllabus, the objectives and tasks of the course should be listed in detail. In the process of artistic practice, the teacher can organize the students to discuss. For some professional problems, the students should be instructed in time to enable the students to successfully complete the established tasks. Finally, they can finish the activities. At the time, the problems in the process are summarized, so that students can improve their majors through art practice activities, and gain different benefits in this art practice.

Form a student's evaluation and comparison of the course. Each student's ability is different, and the learning will be very different, but they can all be intuitively seen to have the disadvantages of others, and to evaluate them objectively. This evaluation link should be of great help to improve students' enthusiasm. And eventually can strengthen the practical teaching link. Establish an art practice leadership team. The faculty can set up some leading groups to actively cooperate and carry out their duties when the school carries out some practical activities, so that students can come out of the classroom, and through these rich practical activities, students can On the basis of classroom learning, conduct more in-depth study and understanding to improve your practical ability.

Schools should organize more art activities, let students "go out", feel the music in nature, organize various evening activities, vocal music and piano performance, encourage students to participate, exercise themselves, and find problems in practice. The school asked teachers and famous artists to perform in the faculty to give students more appreciation and learning opportunities.

\subsection{Teaching principles of art practice classroom}

Vigorously advocate a relaxed learning environment. The variety of teaching styles of art practice classes, different grades and different students will be different. Teachers should adjust the content of teaching according to these specific situations, and formulate some specific teaching plans. Free learning in the environment, bold performances, in order to cultivate students' expressiveness. Teachers should overcome the simple method of teaching and teaching, so that the combination of on-site and off-site, practitioners can learn to be brave, and boldly innovate, which is of great help to students to establish a good practice mentality. Regulate practice through problems encountered by students in practical activities. Summarize some of the performance problems of musicians in the past and current activities to develop the future, which can help them achieve the desired training goals. Therefore, in the activities of teaching, we should pay enough attention to the practice of music and art to ensure the stable development of music and art education.

Classroom and stage combination. In the traditional teaching concept, the teaching of music art practice is done in the classroom or in the piano room. Therefore, this has a great impact on the effect of practical teaching. In the school, the opportunities for students to enter the stage are limited, which makes students more hindered in improving their practical ability. And the practical ability of music majors ultimately needs to be tested on the stage. Therefore, the classroom is transferred to the stage to carry out practical teaching, effectively promoting the results of practical teaching. The school is integrated with the school. On the one hand, actively participate in various large-scale 
cultural performances in the school, on the other hand, actively participate in various educational internships and various professional competitions outside the school. Participating in performances on campus is a demonstration of the artistic achievements of students, and an art education for ordinary college students. It injects new elements into traditional cultural brands and promotes its normative and sustainable development.

\section{Exploring the cultivation of students' innovative ability by carrying out artistic practice activities}

In the art practice activities, let the students do as much as possible, boldly use the imagination space, and make the content and form of the activity with their own unique personality. This link should show enough attention. Of course, the content of each semester must be Different, the form should be as diverse as possible. For example, you can carry out activities around the performance of some performances, or you can cooperate with other universities to organize some competitions, so that students will show great interest in these practical activities. I feel that the activities are boring. At the same time, some problems that arise in practical activities should be seriously considered and solved, so that students can show high enthusiasm when participating in each practical activity.

The practice of music lessons is particularly strong. In the classroom, teachers should take students as the main body. When learning a certain work, not only must we carefully analyze the music theory, but also understand the emotions and creative background contained in it, so that students can be in others. Summarize the experience in the work and try to create some of your favorite songs. Therefore, higher normal colleges can set up some student art practice centers to plan and organize some concerts, so that students can fully exert their abilities and improve their innovative ability on this practical platform.

Innovate classroom teaching methods and cultivate innovative practice skills. In the process of music teaching, we should continue to innovate and innovate the teaching mode. Teachers should adjust the rhythm of teaching in the process of teaching. Some methods should be used to do some classroom problems. Students must pass a reflection. The problem process is only after the problem is solved. To give students a time and space to think and imagine problems, and to give them the opportunity to explore, it is precisely such a process of thinking and exploration, which will stimulate students to develop their thinking, and then will be tempered and ultimately achieve innovative ability. improve.

\section{Conclusion}

To sum up, the artistic practice of music major has a very important factor in the cultivation of innovative ability. Students in this special subject of music major are relatively abstract things in their study. Students should be based on a certain understanding before they can learn easily. Innovative ability requires students to have a strong feeling ability and create more genres that are quite different from the existing music forms in the field of music. Schools should gradually implement a series of educational methods different from the traditional ones, break down the stereotypes and inspire students' innovative ability with more effective educational methods.

Art can develop people's intelligence very well, so now more and more people choose to let their children touch music and learn music from childhood. The ability to innovate makes people and society progress and develop continuously. Therefore, these two factors will be explored and perfected forever. The entry of the society and the prosperity of the nation depend on the new generation of young people, and the correct training of college students cannot be ignored. 


\section{References}

[1] Liu Dong. The role of artistic practice in cultivating students' innovative ability in normal universities [J]. Music World, 2015 (11).

[2] Zhu Yanbin. Art Practice - An Important Way to Cultivate Vocal Performance Talents [J]. Hua Zhang, 2011 (24).

[3] Shang Хиеуu. Exploration of music art practice in ordinary universities [D]. Capital Normal University, 2006.

[4] Peng Hui. Research on the Function and System of Cultivating College Students' Artistic Innovation Ability [J]. Frontier Economy and Culture, 2011 (4).

[5] Chen Liping. Bringing Innovation into Music Class [J]. Intelligence, 2012 (7).

[6] Wei Xinnan. Talk about continuous innovation in music teaching [J]. Northern Literature (the second half of the month), 2010 (6).

[7] Yin Jingmin. Talking about the Role of Art Practice in Cultivating Innovative Ability of Music Majors in Colleges and Universities [J]. Hua Zhang, 2011 (9)

[8] Meng Yuanyuan. How to cultivate students' innovative ability in music teaching [J]. Examinations Weekly, 2013 (33).

[9] Tian Feng. Pay attention to music art practice and give full play to students' awareness of participation [J]. China's off-campus education (Basic Education Edition), 2011 (5) 